\title{
Climate change projections for the Torres Strait region
}

\author{
R. Suppiah, M. A. Collier and D. Kent \\ Centre for Australian Weather and Climate Research (CAWCR), CSIRO Marine and Atmospheric Research, \\ Melbourne, Australia \\ Email: suppiah.ramasamy@,csiro.au
}

\begin{abstract}
The Torres Strait Island region extends from the Cape York Peninsula to within $5 \mathrm{~km}$ of the Papua New Guinea (PNG) coastline. The specific objectives of this paper are to provide a brief discussion on observed climate of the region and also to provide future climate change projections for a number of variables using CMIP3 models.
\end{abstract}

Due to the location, the region experiences high solar radiation, air and sea surface temperatures and relative humidity throughout the year and high rainfall during the wet season associated with the monsoon. The annual average temperature increased by $0.25^{\circ} \mathrm{C}$ per decade from 1960 to mid $1990 \mathrm{~s}$ and by $0.51^{\circ} \mathrm{C}$ per decade from mid 1990 s to 2009 . The annual apparent temperature is $38.4^{\circ} \mathrm{C}$ compared to the annual air temperature of $26.8^{\circ} \mathrm{C}$. The rainfall variability of the region is influenced by El Niño-Southern Oscillation on the interannual time scale and Madden-Julian oscillation on the intra-seasonal time scale. Extreme rainfall events tend to occur during the monsoon season and drier conditions associated with southeast trade winds.

Best estimates of annual changes and ranges of uncertainty in climate variables are given for 2030, 2050 and 2070 for SRES A2 and A1FI emission scenarios using CMIP3 simulations and changes in seasonal values are given in Suppiah et al. (2010). The best estimate for annual average temperature increase by 2030 is $0.9^{\circ} \mathrm{C}$, with a range of uncertainty of 0.6 to $1.1^{\circ} \mathrm{C}$ for the $\mathrm{A} 2$ emission scenario. For the A1FI emission scenario the annual increase by 2030 is $1.0{ }^{\circ} \mathrm{C}$ with the range of uncertainty of 0.7 to $1.3{ }^{\circ} \mathrm{C}$. The projected increase in the average annual apparent temperature for the $\mathrm{A} 2$ emission scenario by 2030 is $1.3{ }^{\circ} \mathrm{C}$ with a range of uncertainty of 0.9 to $1.7^{\circ} \mathrm{C}$, and for the A1FI emission scenario is $1.6{ }^{\circ} \mathrm{C}$ with a range of uncertainty of 1.0 to $2.0^{\circ} \mathrm{C}$. Best annual estimates are 2.3 and $3.2^{\circ} \mathrm{C}$ for the $\mathrm{A} 2$ emission scenario and 2.7 and $3.8^{\circ} \mathrm{C}$ for the A1FI emission scenario for 2050 and 2070.

Projected rainfall changes show a slight increase. The best estimate of regional average annual rainfall change for the A2 emission scenario for 2030 is $+1.2 \%$ with a range of uncertainty of -3.0 to $+5.3 \%$. For the A1FI emission scenario the best estimate for 2030 is $+1.5 \%$ with the range of uncertainty of -3.5 to $+6.3 \%$. Larger ranges and slight increases in means are projected for 2050 and 2070. An increase in potential evaporation is projected. The best estimate of annual increase by 2030 for the A2 emission scenario is $2.6 \%$ with an uncertainty range between 1.9 and 4.7\%. For the A1FI emission scenario, the annual increase by 2030 is $3.7 \%$ with an uncertainty range between 2.3 and $5.9 \%$. Small changes are projected for solar radiation, relative humidity and winds speed. Of the climate variables investigated in this study those expected to show the most significant changes due to climate change are rainfall (increase in the wet season), apparent and atmospheric temperature and potential evaporation.

Sea level rise due to climate change is expected to pose the greatest threat to island communities. Tide gauge data from the region suggest sea level rise of $6 \mathrm{~mm}$ per year between 1993 and 2010, twice the global average. It is likely that increases in sea level will not be linear. Current warming of the oceans and atmosphere are likely to drive an increase in global sea level for at least several centuries, even if we drastically reduce the greenhouse gases emissions at present.

The practical implications of these projections suggest possible widespread impact across the region. Such impact can significantly affect marine and terrestrial ecosystem health, agricultural productivity, water resources, fisheries, human health, human migration, tourism, and pest abundance and distribution in the region.

Keywords: Torres Strait Region, North Australian wet season, Climate change projection, sea level rise, apparent temperature. 


\section{INTRODUCTION}

The Torres Strait Island region extends from the Cape York Peninsula to within $5 \mathrm{~km}$ of the Papua New Guinea (PNG) coastline (Figure 1). The outer larger islands consist of the western islands (Badu, Moa, Mabuiag), the north-western islands (Boigu, Dauan, Saibai), the eastern islands (Ugar, Erub, Mer) and the central islands (Masig, Poruma, Warraber, Iama). Thursday, Horn, Prince of Wales, Friday Islands and others are located in the southern part of the region. Recent estimates shows the population of the Torres Strait at about 6500 , with 3500 living on either the administrative centre of Thursday Island or on nearby islands, and the remainder living on 13 islands (Briggs, 2010). Results presented in this paper are based on a research project on climate change in this region. Further details are available in Suppiah et al (2010).

Figure 1 shows the locations of the domain that covers the Torres Strait region.

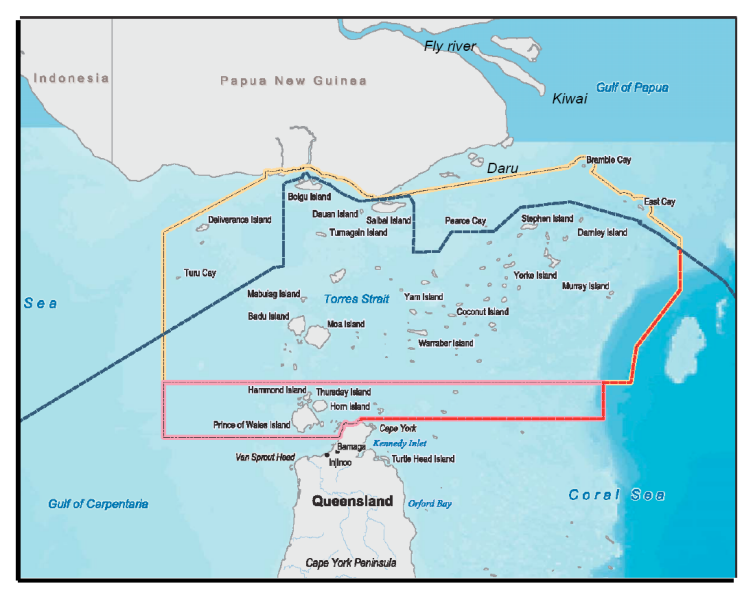

Figure 1. The Torres Strait region. The yellow line delimits the Torres Strait Protected Zone established under the Torres Strait Treaty. The pink line delimits the inner islands. The blue line is the boundary between Australia and PNG. (Source: National Oceans Office).
The Torres Strait region has diverse marine and fishery resources which are bases for the region's future economic development (TSRA, 2010). Some species are over-fished while there is uncertainty about the status of others. Key community-driven policy initiatives aiming to achieve sustainable economic and cultural development include the Torres Strait Regional Authority (TSRA) Land and Sea Management Strategy, the Torres Strait and Northern Peninsula Area Regional Plan, and the Torres Strait Development Plan. The indigenous people of the Torres Strait have a unique culture sharing some characteristics with other indigenous Australians. Archaeological, linguistic and folk history evidence suggests that the core of Island culture is linked to both Australia and other Pacific islands. People from these islands were traditionally agriculturalists although they supplemented their food supplies through hunting and gathering. The economy of the region remarkably relies on fishing, pearling, sponge farming and tourism (TSRA, 2010). Coral reef in this region is also affected by anomalous changes in sea surface temperature.

Climate change due to the increase in greenhouse gas concentrations is now inevitable (IPCC, 2007). Climate change will continue to impact until (and to lesser known degree beyond) a stabilisation and subsequent reduction of greenhouse gas concentration in the atmosphere can be achieved. We therefore need the best possible estimates of regional climate changes and of the sensitivity of natural, economical and social sectors to such changes. In this paper, climate change projections are provided based on simulations from 24 global climate models (GCMs) used for the Intergovernmental Panel on Climate Change (IPCC) Fourth Assessment Report (IPCC, 2007). We provide climate change projections based on high (SRES A2) and very high (SRES A1FI) emission scenarios (Nakićenović, and Swart, 2000). .

The specific objectives of this paper are to: (a) Provide a brief discussion on observed climate and climate drivers of the region and trends and variations in observed climate variables, such as, temperature rainfall, solar radiation, cloudy days, and sea level rise (Section 2). (b) Provide a description of the methodology and its related uncertainties used to generate climate change projections (Section 3). (c) Provide climate change projections for a number of simulated variables (Section 4).

\section{CLIMATES OF THE TORRES STRAIT REGION}

The Torres Strait region's climate is influenced by the summer monsoon between December to February and by southeast trade winds during the rest of the year. During summer, the Australian monsoon brings humid and rainy conditions to northern Australia. On average, the arrival ('onset') of the monsoon occurs between late December and early January (long-term average December 28) (McBride, 1987; Suppiah, 1992; Smith et $a l$, 2008). Strong westerly winds and heavy rainfall are associated with the onset. A fully developed monsoon circulation system is comprised of at least three distinct weather patterns: the active, moderate and break phases of the monsoon. Their occurrence is associated with variations in the strength of the entire monsoon 
system within seasons and from year to year. The active phase is more energetic than the moderate phase, with stronger westerlies, an intense tropical monsoon trough and enhanced rainfall. Intense depressions and tropical cyclones often form during the active phase along the monsoon trough (McBride and Keenan, 1982). The break, or dormant phase, is associated with weak westerlies and little or no rainfall, while the moderate phase has average monsoon conditions, between active and break phases. The monsoon is one of the dominant climate drivers that affects the climate and climate variability of the Torres Strait region. Cold wind surges, which mainly develop over East Asia, propagate towards northern Australia after crossing the South China Sea (Suppiah and Wu, 1998). Strong winds and heavy rainfall are associated with these cold surges, particularly during the Australian monsoon season. The frequency of strong wind events is usually high before the onset and active phase of the monsoon.

Seasonal westerly winds dominate the climate as the summer approaches. Winds from the northern hemisphere reach the region after accumulating moisture from the Indonesian region and give enhanced rainfall from December to March. This type of synoptic situation results in heavy rainfall events in tropical rainforest, Cape York and Torres Strait regions. South-east trades dominate the winter/dry season. Due to its location, the Torres Strait region experiences high temperature through out the year. The mean annual temperature is around $27^{\circ} \mathrm{C}$ with a relatively small range from $25^{\circ} \mathrm{C}$ to $28^{\circ} \mathrm{C}$.

\subsection{Rainfall Variability, ISO, ENSO and sea level rise}

Rainfall variability in the region is influenced by tropical intra-seasonal oscillation (ISO) on a 30-50 day time scale and also by El Niño-Southern oscillation (ENSO) on an inter-annual time scale. Pacific Decadal Oscillation (PDO) operates on multi-decadal time scales. Daily rainfall at Thursday Island (Figure 2a) shows variation on the ISO time scale. The influence of ISO is strong during the monsoon season (between December and February) and hence, is phased-locked to the seasonal cycle. Annual rainfall for the wet season (October to April) for the southern part of the region (1890-2010) (Figure 2b) shows strong variations on inter-annual and inter-decadal time scales. The $1960 \mathrm{~s}$ and $1990 \mathrm{~s}$ were dry by $-9.0 \%$ and $-0.4 \%$ and the 1970 s and recent years were relatively wet by 10 and 6\%, respectively. Wet years are associated with La Niña years as indicated by positive Southern oscillation Index (SOI) values and dry years are linked to El Niño years as shown by negative SOI values.

Severe tropical cyclones are rare in the region. However, tropical cyclones crossing the Cape York Peninsula can pose a significant threat through stronger winds, waves and storm surges. Further details of the impacts of cyclones on the region can be found in Green et al. (2010). Inter-annual variability in the sea level is strongly associated with ENSO variability. Sea level anomalies in the Torres Strait region show an increasing trend with strong short-term and inter-annual variability. The increase in mean sea level is $6 \mathrm{~mm}$ per year between 1993 and 2010 for the region, which is twice the global average sea level change ( 3 mm per year) given by Mitchum et al. (2010). The sea level also shows strong inter-annual variability associated with ENSO. Sea levels were lower during El Niño years and higher during La Niña years. El Niño years, such as 1997-1998, 2002-2003 and 2006-2007, show negative anomalies of sea level.
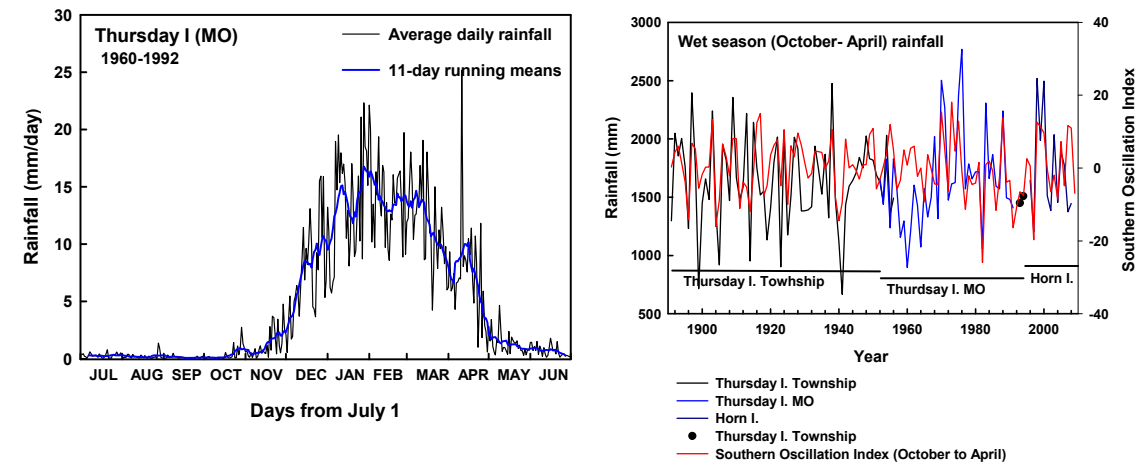

Figure 2. Mean daily (a) and annual wet season (b) rainfall variations at Thursday Island.

\subsection{Air, sea surface and apparent temperatures}

The annual average air temperature over the Torres Strait region is $26.8^{\circ} \mathrm{C}$. December is the warmest month with $28.1{ }^{\circ} \mathrm{C}$, while August is the coolest month with $25.3{ }^{\circ} \mathrm{C}$. Figure 3 shows trends and variability in 
maximum, minimum and mean temperatures at Thursday Island. Due to the lack of a continuous record at one station, temperature data from near by stations are used to investigate the long-term variations and trends. Since 1960, maximum, minimum and mean temperatures at Thursday-Horn Islands show a positive trend with strong inter-annual variability. The maximum and minimum temperatures increased by $0.32{ }^{\circ} \mathrm{C}$ and $0.18^{\circ} \mathrm{C}$ per decade between 1960 and the mid 1990s. From the mid 1990s to 2009, maximum and minimum temperatures increased by $0.67{ }^{\circ} \mathrm{C}$ and $0.35{ }^{\circ} \mathrm{C}$ per decade. The mean temperature increased by $0.25{ }^{\circ} \mathrm{C}$ per decade between 1960 and the mid 1990s and by $0.51^{\circ} \mathrm{C}$ per decade from the mid 1990s and 2009. Since the increases in the later period were drawn from a smaller sample, caution is needed when interpreting the results.
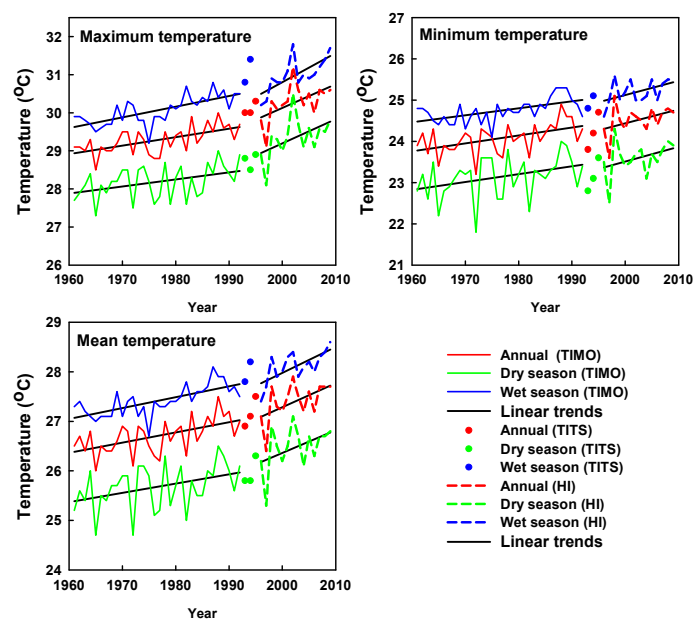

Figure 3. Trends and variability in annual (red), wet (blue) and dry (green) seasons' maximum, minimum and mean temperatures at Thursday Island. TIMO: Thursday Island Met. Office, TITS: Thursday Island Township and HI: Horn Island. Linear trends are shown by black lines. Data source: Australian Bureau of Meteorology.

The average annual sea surface temperature (SST) in the region is $28.0{ }^{\circ} \mathrm{C}$ and shows small variation throughout the year. The long-term average SST for the wet season is $28.3{ }^{\circ} \mathrm{C}$ and for the dry season is $27.4{ }^{\circ} \mathrm{C}$. The average annual SST in the region has risen by 0.16 to $0.18{ }^{\circ} \mathrm{C}$ per decade from 1950 to present. Increases in SST can have major implications for marine ecosystems and fisheries. Whilst expected changes in SST are not included in this study, an average increase in SST of $2{ }^{\circ} \mathrm{C}$ in tropical Australia is expected to lead to annual bleaching with $97 \%$ of reefs affected (Johnson and Marshall, 2007).

Apparent temperature refers to how combinations of air temperature, humidity, solar radiation and wind speed feel to humans, based on physiology and clothing. Apparent temperatures have been calculated using area-averaged monthly values of net radiation and air temperature, relative humidity and wind speed at 10 meters for individual years, from 1948 to 2009 from the National Center for Environmental Prediction (NCEP) re-analysis (Kalnay et al., 1996). The annual apparent temperature is $38.4{ }^{\circ} \mathrm{C}$ compared to the annual air temperature of $26.8^{\circ} \mathrm{C}$, that is about $12{ }^{\circ} \mathrm{C}$ higher due to other climatic factors. The average wet season apparent temperature is $43.8^{\circ} \mathrm{C}$ and for the dry season is $33.6{ }^{\circ} \mathrm{C}$. Higher apparent temperature is a result of high relative humidity throughout the year, more intense solar radiation and weaker winds during the wet season (and vice versa for the dry season). High apparent temperatures can also lead to health impacts such as fatigue and heat stress, particularly to the sick and aged population.

Year to year changes in apparent temperature are shown in Figure 4 and do not show a clear longterm trend, but the last decade shows a small decline with reduced variability. Since annual temperature does not contribute to such reduced variability, it is possible to assume that other variables mentioned earlier might have significant influences. However, such a decrease does not contribute much to comfort to the population in the region, as apparent temperatures are always high.

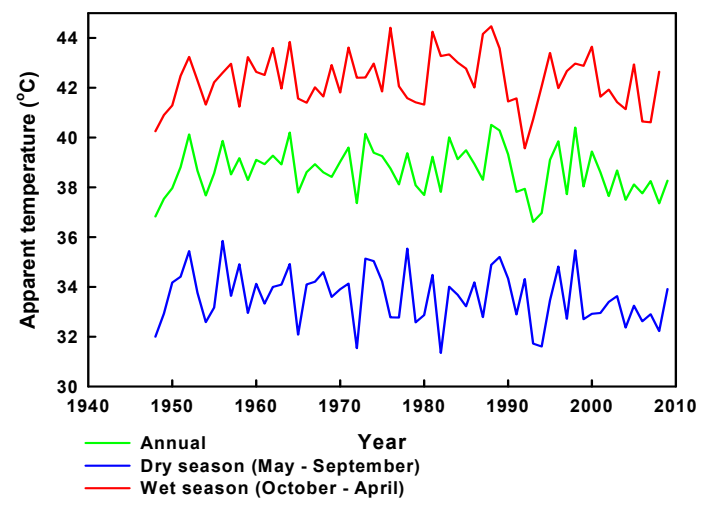

Figure 4. Year to year variability in annual, wet and dry season apparent temperatures in the Torres Strait region.

\section{METHODS FOR PRODUCING FUTURE CLIMATE CHANGE PROJECTIONS}

The CSIRO and Bureau of Meteorology (2007) Technical Report describes the methodology in detail used to synthesize climate model projections for Australia. The same method has been applied here to generate 
projections at the regional scale. There are three major uncertainties associated with future climate change projections. They are (1) the uncertainty in the future evolution of greenhouse gas and sulphate aerosol emissions of which global economic output and population growth are important determining factors. (2) the uncertainty in how much the global average surface temperature will respond to increases in atmospheric greenhouse gas concentrations and changes in sulphate aerosol emissions and (3) the uncertainty in how the climate of Australia will respond to an increase in global average surface temperature. Discussions on these uncertainties are given in Suppiah et al. (2010).

Model simulations performed for the Fourth Assessment Report of the IPCC were processed using the pattern scaling technique described by Whetton et al. (2005). From the simulations of the $21^{\text {st }}$ century from each model, the trend in each variable and each model grid point was calculated, relative to the global mean temperature trend. The results from the 24 models were then combined to form a probability distribution for local change per degree of warming. In this process, models were given differing weights, or emphasis, depending on their ability to simulate average patterns of temperature, precipitation and mean sea level pressure in the Australian region for the 30-year period, 1961-1990 (Watterson, 2008). Projected changes in climate variables are expressed in terms of 50th, 10th and $90^{\text {th }}$ percentiles. The $50^{\text {th }}$ percentile represents the median or mid value, while $10^{\text {th }}$ and $90^{\text {th }}$ percentiles represent lower and upper ranges of projections (CSIRO and Bureau of Meteorology (2007). Projections are created for individual climate variables, for selected time periods and emissions scenarios, A2 and A1FI as the request of TSRA. Projections from different climate models are often grouped (an ensemble) then expressed as a range of values to represent the uncertainty, e.g. warming of $1-2{ }^{\circ} \mathrm{C}$ and rainfall decrease of $5-10 \%$ by 2030.

\section{PROJECTED CLIMATE CHANGE OF THE REGION}

Projected changes in annual solar radiation, maximum, minimum and mean temperatures, apparent temperature, rainfall, relative humidity, wind speed and potential evaporation for SRES A2 and A1FI emission scenarios for 2030, 2050 and 2070 are given in Tables 1 and 2. Discussion is focused on 2030 due to limit on the length of the paper, but results are available for other years in following Tables.

Table 1. Projected annual changes and their ranges in solar radiation (\%), maximum, minimum and mean temperatures $\left({ }^{\circ} \mathrm{C}\right)$, apparent temperature $\left({ }^{\circ} \mathrm{C}\right)$, rainfall $(\%)$, relative humidity $(\%)$, wind speed $(\%)$ and potential evaporation (\%) for SRES A2 emission scenarios for 2030, 2050 and 2070 for the region.

\begin{tabular}{|l|ccc|ccc|ccc|}
\hline $\begin{array}{c}\text { Climate } \\
\text { Variable/Year }\end{array}$ & \multicolumn{3}{|c|}{$\mathbf{2 0 3 0}$} & \multicolumn{3}{c|}{$\mathbf{2 0 5 0}$} & \multicolumn{3}{c|}{$\mathbf{2 0 7 0}$} \\
\hline Percentiles & $\mathbf{1 0}^{\text {th }}$ & $\mathbf{5 0}^{\text {th }}$ & $\mathbf{9 0}^{\text {th }}$ & $\mathbf{1 0}^{\text {th }}$ & $\mathbf{5 0}^{\text {th }}$ & $\mathbf{9 0}^{\text {th }}$ & $\mathbf{1 0}^{\text {th }}$ & $\mathbf{5 0}^{\text {th }}$ & $\mathbf{9 0}^{\text {th }}$ \\
\hline Solar rad. $(\%)$ & -1.18 & -0.31 & 0.82 & -2.01 & -0.54 & 1.41 & -2.79 & -0.79 & 2.09 \\
Max.Temp. $\left({ }^{\circ} \mathrm{C}\right)$ & 0.55 & 0.73 & 1.10 & 0.95 & 1.25 & 1.88 & 1.50 & 1.76 & 2.72 \\
Min. Temp. $\left({ }^{\circ} \mathrm{C}\right)$ & 0.55 & 0.79 & 1.05 & 0.96 & 1.35 & 1.80 & 1.52 & 1.93 & 2.60 \\
Mean Temp. $\left({ }^{\circ} \mathrm{C}\right)$ & 0.62 & 0.87 & 1.08 & 1.08 & 1.48 & 1.83 & 1.65 & 2.07 & 2.56 \\
App. Temp. $\left({ }^{\circ} \mathrm{C}\right)$ & 0.87 & 1.32 & 1.70 & 1.55 & 2.29 & 2.92 & 2.43 & 3.24 & 4.08 \\
Rainfall $(\%)$ & -2.97 & 1.24 & 5.33 & -5.09 & 2.14 & 9.19 & -7.57 & 3.21 & 14.09 \\
Rel. Hum. $(\%)$ & -0.58 & -0.04 & 0.20 & -0.99 & -0.08 & 0.34 & -1.38 & -0.11 & 0.48 \\
Wind speed (\%) & -0.95 & 0.34 & 1.72 & -1.62 & 0.59 & 2.96 & -2.31 & 0.74 & 4.96 \\
Pot. Evap. $(\%)$ & 1.94 & 2.63 & 4.72 & 3.37 & 4.53 & 8.11 & 4.96 & 6.69 & 11.97 \\
\hline
\end{tabular}

Solar radiation: The best estimates of annual changes in solar radiation by 2030 for A2 and A1FI emission scenarios are $-0.3 \%$ and $-0.4 \%$, with ranges between $-1.2 \%$ and $0.8 \%$ and between $-1.4 \%$ and $0.8 \%$, respectively.

Maximum temperature: The best estimate for regional annual average maximum temperature increase by 2030 is $0.7{ }^{\circ} \mathrm{C}$, with a range of uncertainty of 0.6 to $1.1{ }^{\circ} \mathrm{C}$ for the $\mathrm{A} 2$ emission scenario. For the A1FI emission scenario the annual increase by 2030 is $0.9^{\circ} \mathrm{C}$ with the range of uncertainty of 0.7 to $1.4^{\circ} \mathrm{C}$.

Minimum temperature: The best estimate for regional annual average minimum temperature increase by 2030 is $0.8{ }^{\circ} \mathrm{C}$, with a range of uncertainty of 0.6 to $1.1{ }^{\circ} \mathrm{C}$ for the $\mathrm{A} 2$ emission scenario. For the A1FI emission scenario the annual increase by 2030 is $1.0^{\circ} \mathrm{C}$ with the range of uncertainty of 0.7 to $1.3{ }^{\circ} \mathrm{C}$.

Mean temperature: The best estimate for regional annual average mean temperature increase by 2030 is 0.9 ${ }^{\circ} \mathrm{C}$, with a range of uncertainty of 0.6 to $1.1^{\circ} \mathrm{C}$ for the $\mathrm{A} 2$ emission scenario. For the A1FI emission scenario the annual increase by 2030 is $1.0^{\circ} \mathrm{C}$ with the range of uncertainty of 0.7 to $1.3{ }^{\circ} \mathrm{C}$. 
Apparent temperature: The projected increase in the average annual apparent temperature for the $\mathrm{A} 2$ emission scenario by 2030 is $1.3{ }^{\circ} \mathrm{C}$ with a range of uncertainty of 0.9 to $1.7^{\circ} \mathrm{C}$, and for the $\mathrm{A} 1 \mathrm{FI}$ emission scenario is $1.6{ }^{\circ} \mathrm{C}$ with a range of uncertainty of 1.0 to $2.0{ }^{\circ} \mathrm{C}$. Differences in projected changes among seasonal values are small. Increases in apparent temperature are larger under climate change conditions due to changes in air temperature and wind speed, as changes in relative humidity and solar radiation are small.

Table 2. Projected annual changes and their ranges in solar radiation (\%), maximum, minimum and mean temperatures $\left({ }^{\circ} \mathrm{C}\right)$, apparent temperature $\left({ }^{\circ} \mathrm{C}\right)$, rainfall $(\%)$, relative humidity $(\%)$, wind speed $(\%)$ and potential evaporation for SRES A1FI emission scenarios for 2030, 2050 and 2070 for the region.

\begin{tabular}{|l|ccc|ccc|ccc|}
\hline $\begin{array}{c}\text { Climate } \\
\text { Variable/Year }\end{array}$ & \multicolumn{3}{|c|}{$\mathbf{2 0 3 0}$} & \multicolumn{3}{c|}{$\mathbf{2 0 5 0}$} & \multicolumn{3}{c|}{$\mathbf{2 0 7 0}$} \\
\hline Percentiles & $\mathbf{1 0}^{\text {th }}$ & $\mathbf{5 0}^{\text {th }}$ & $\mathbf{9 0}^{\text {th }}$ & $\mathbf{1 0}^{\text {th }}$ & $\mathbf{5 0}^{\text {th }}$ & $\mathbf{9 0}^{\text {th }}$ & $\mathbf{1 0}^{\text {th }}$ & $\mathbf{5 0}^{\text {th }}$ & $\mathbf{9 0}^{\text {th }}$ \\
\hline Solar rad. (\%) & -1.39 & -0.43 & 0.81 & -2.36 & -0.74 & 1.42 & -3.29 & -1.10 & 2.28 \\
Max.Temp. $\left({ }^{\circ} \mathrm{C}\right)$ & 0.65 & 0.90 & 1.38 & 1.12 & 1.53 & 2.35 & 1.74 & 2.13 & 3.31 \\
Min. Temp. $\left({ }^{\circ} \mathrm{C}\right)$ & 0.65 & 0.98 & 1.31 & 1.13 & 1.67 & 2.24 & 1.75 & 2.33 & 3.16 \\
Mean Temp. $\left({ }^{\circ} \mathrm{C}\right)$ & 0.73 & 1.02 & 1.27 & 1.27 & 1.74 & 2.16 & 1.94 & 2.44 & 3.01 \\
App. Temp. $\left({ }^{\circ} \mathrm{C}\right)$ & 1.03 & 1.56 & 1.96 & 1.84 & 2.70 & 3.39 & 2.87 & 3.82 & 4.81 \\
Rainfall $(\%)$ & -3.49 & 1.46 & 6.27 & -5.99 & 2.52 & 10.81 & -8.90 & 3.78 & 16.57 \\
Rel. Hum. $(\%)$ & -0.69 & -0.05 & 0.23 & -1.17 & -0.09 & 0.40 & -1.63 & -0.12 & 0.56 \\
Wind speed (\%) & -1.12 & 0.37 & 2.47 & -1.91 & 0.63 & 4.19 & -2.72 & 0.87 & 5.84 \\
Pot. Evap. (\%) & 2.28 & 3.74 & 5.87 & 3.96 & 6.35 & 10.05 & 5.84 & 8.84 & 14.54 \\
\hline
\end{tabular}

Rainfall: Projected rainfall shows a slight increase. The best estimate of regional average annual rainfall change for the A2 emission scenario for 2030 is $+1.2 \%$ with a range of uncertainty of -3.0 to $+5.3 \%$. For the A1FI emission scenario the best estimate for 2030 is $+1.5 \%$ with the range of uncertainty of -3.5 to $+6.3 \%$. Increases are relatively larger for December to February, March to May and September to November compared with June to August.

Relative humidity: Due to the location in the tropics, relative humidity is constantly high during the year in the Torres Strait region. However, changes in relative humidity in the future are projected to be less than $1 \%$ ranging between -1 and $+1 \%$.

Wind speed: Changes to annual wind speed are also expected to be small. The best estimate for annual wind speed change by 2030 for the A2 emission scenario is $+0.3 \%$ with a range between -1.0 and $1.7 \%$. For the A1FI emission scenario, the annual change is $+0.4 \%$ with a range between -1.1 and $2.5 \%$.

Potential evaporation: Overall there is an increase in potential evaporation in the future with the greatest increase under the A1FI emission scenario. The best estimate of annual increase by 2030 for the A2 emission scenario is $2.6 \%$ with an uncertainty range between 1.9 and $4.7 \%$. For the A1FI emission scenario, the annual increase by 2030 is $3.7 \%$ with an uncertainty range between 2.3 and $5.9 \%$.

Sea level rise: Observed data from the region show sea level rise of $6 \mathrm{~mm}$ per year between 1993 and 2010, twice the global average given by Mitchum et al. (2010). The IPCC predicts up to $0.8 \mathrm{~m}$ sea level rise by 2100 , but higher levels cannot be excluded. It is likely that increases in sea level will not be linear. Current warming of the oceans and atmosphere are likely to drive an increase in global sea level for at least several centuries, even if we drastically reduce the greenhouse gases emissions at present.

\section{CONCLUSIONS AND RECOMMENDATIONS}

Simulated changes in climate indicate that a significant degree of climate change in the Torres Strait region is inevitable, and likely to become increasingly apparent over the next 20-100 years. The present study shows that changes are expected in mean values. Therefore future planning and adaptation strategies should consider that future climate and resources will not be as they were observed over the past century.

Characteristics of water quality, flooding areas and storm surges could change significantly due to changes in climate drivers operating in the region, particularly monsoon, ENSO and tropical cyclones affecting northeastern Australia. Anticipated changes have significant implications for the sustainable development of planned infrastructure including coastal development, industry and bridges.

Generally, communities in the Torres Strait are accustomed to higher apparent temperatures than people on the mainland interior. However, but communities will need to consider how they might respond to predicted 
increases in apparent temperature, in order to avoid negative impacts to health and productivity. Changes in apparent temperature could be very detrimental to the human population of the region. These changes would affect daily life, the economic livelihood of inhabitants and the ecosystem within the region. Significant changes in management may be required for adaptation strategies to ensure sustainability.

An increase in summer rainfall may increase the risk of flooding and erosion. Increased variability will have implications for food production, rainwater supplies and the entire region's ecosystem. Increases in potential evaporation may have significant implications for ground water and fresh water supplies, with consequences for both communities and island ecosystems. Some plant and fish species may come under increasing stress, causing long-term irreversible change in species composition. Changes in characteristics of ENSO, and sea level rise at decadal and century scales are expected to affect the region.

\section{ACKNOWLEDGMENTS}

This work was produced by CSIRO, Marine and Atmospheric Research under the contract to the Land and Sea Management Unit of the Torres Strait Regional Authority. This work also contributes to Climate and Adaptation Flagship. Financial support from the Torres Strait Regional Authority is also acknowledged.

\section{REFERENCES}

Briggs, G. 2010. The impact of climate change on the Torres Strait and Australia's Indian Ocean territories. Strategic analysis paper, Independent Strategic Analysis of Australia’s Global Interests, March 2010, 7p.

CSIRO and Australian Bureau of Meteorology, 2007: Climate change in Australia. Technical Report, 140 pp,

Green, D., Alexander, L., McInnes, K., Church, J., Nicholls, N. and White, N. 2010: An assessment of climate change impacts and adaptation for the Torres Strait Islands, Australia. Clim. Change, 102, 405433.

IPCC, 2007: Climate Change 2007: The Physical Science - Summary for Policymakers. Contribution of Working Group I to the Fourth Assessment Report of the Intergovernmental Panel on Clim. Change, 17p..

Johnson, J. E. and Marshall, P. A. 2007: Climate change and the Great Barrier Reef. A Vulnerability Assessment. Great Barrier Reef Marine Park Authority and Australian Greenhouse Office, Australia.

Kalnay, E.. and 21 others (1996), The NCEP-NCAR 40-year reanalysis project. Bull. Am. Met. Soc., 77, 437470.

McBride, J. L. 1987: The Australian monsoon. In: Monsoon Meteorology, C. P Chang and T. N. Krishnamurti, Eds., Oxford University Press, 203-231.

McBride, J. L. and Keenan, T. D. 1982: Climatology of tropical cyclone genesis in the Australian region. Inter. Jour. Climatol., 2, 13-33.

Mitchum, G. T., Nerem, R. S., Merrifield, M. A. and Gehrels, W. R. 2010: Model sea level change estimates. In: Understanding sea-level rise and variability, Eds. J. A. Church, P. L. Woodworth, T. Aarup and W. S. Wilson, Wiley-Blackwell, Chichester, UK, 122-142.

Nakićenović, N., and Swart, R. (Eds.), 2000: Special Report on Emissions Scenarios. A Special Report of Working Group III of the Intergovernmental Panel on Climate Change, Cambridge University Press, Cambridge, United Kingdom and New York, NY, USA, 599 pp.

Smith, I. N., Wilson, L. and Suppiah, R. 2008: Characteristics of the northern Australian rainy season. $J$. Clim., 21, 4298-4311.

Suppiah, R. 1992: The Australian summer monsoon: A review. Prog. Phy. Geogr., 16, 283-318.

Suppiah, R. and Wu, X. 1998: Surges, cross-equatorial flows and their links with the Australian summer monsoon circulation and rainfall. Australian Meteorological Magazine, 47, 113-130.

Suppiah, R., Bathols, J., Collier, M., Kent, D. and O'Grady, J. 2010: Observed and future climates of the Torres Strait Region. CSIRO, Marine and Atmospheric Research. Report to the Torres Strait Regional Authority, 66p.

TSRA. 2010: Torres Strait Climate Change Strategy. Report prepared by the Land and Sea Management Unit, Torres Strait regional Authority, May 2010, 20p.

Watterson, I.G., 2008: Calculation of probability density functions for temperature and precipitation change under global warming. Journal of Geophysical Research, 113, D12106, doi:10.1029/2007JD009254.

Whetton, P. H., McInnes, K. L., Jones, R. N., Hennessy, K. J., Suppiah, R., Page, C. M., Bathols, J. and Durack, P. J. 2005: Australian climate change projections for impact assessment and policy application : A Review., CSIRO, Marine and Atmospheric Research Paper 001, Aspendale, 34p. 